ISSN 2623-6575

GEASILE
FUTURE

UDK 60

UDK 631

UDK 663

UDK 630

兽

昜

急

를

空

兽

H

䁬

发

急

究

号

$\mathbb{N}$

茠

舀

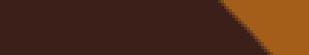




\section{Glasilo Future}

\section{Stručno-znanstveni časopis}

Nakladnik:

FUTURA

\section{FuTU}

Sjedište udruge: Šibenik
Adresa uredništva:

Bana Josipa Jelačića 13 a, 22000 Šibenik, Hrvatska / Croatia

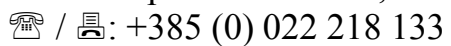

凶: urednistvo@gazette-future.eu / editors@gazette-future.eu

(3): www.gazette-future.eu

Uređivački odbor / Editorial Board:

Doc. dr. sc. Boris Dorbić, v. pred. - glavni i odgovorni urednik / Editor-in-Chief

Emilija Friganović, dipl. ing. preh. teh., v. pred. - zamjenica g. i o. urednika / Deputy Editor-in-Chief

Ančica Sečan Matijaščić, mag. act. soc. - tehnička urednica / Technical Editor

Antonia Dorbić, mag. art. - zamjenica tehničke urednice / Deputy Technical Editor

Prof. dr. sc. Željko Španjol

Mr. sc. Milivoj Blažević

Vesna Štibrić, dipl. ing. preh. teh.

Međunarodno uredništvo / International Editorial Board:

Prof. dr. sc. Kiril Bahcevandziev - Portugal (Instituto Politécnico de Coimbra)

Prof. dr. sc. Martin Bobinac - Srbija (Šumarski fakultet Beograd)

Prof. dr. sc. Zvezda Bogevska - Sjeverna Makedonija (Fakultet za zemjodelski nauki i hrana Skopje)

Dario Bognolo, mag. ing. - Hrvatska (Veleučilište u Rijeci)

Prof. dr. sc. Agata Cieszewska - Poljska (Szkoła Główna Gospodarstwa Wiejskiego w Warszawie)

Dr. sc. Bogdan Cvjetković, prof. emeritus - Hrvatska (Agronomski fakultet Zagreb)

Prof. dr. sc. Duška Ćurić - Hrvatska (Prehrambeno-biotehnološki fakultet Zagreb)

Prof. dr. sc. Margarita Davitkovska - Sjeverna Makedonija (Fakultet za zemjodelski nauki i hrana Skopje)

Prof. dr. sc. Dubravka Dujmović Purgar - Hrvatska (Agronomski fakultet Zagreb)

Prof. dr. sc. Josipa Giljanović - Republika Hrvatska (Kemijsko-tehnološki fakultet u Splitu)

Prof. dr. sc. Semina Hadžiabulić - Bosna i Hercegovina (Agromediteranski fakultet Mostar)

Prof. dr. sc. Péter Honfi - Mađarska (Faculty of Horticultural Science Budapest)

Prof. dr. sc. Valeria Ivanova - Bugarska (Fakultet za lozaro - gradinarstvo Plovdiv)

Prof. dr. sc. Mladen Ivić - Bosna i Hercegovina (Univerzitet PIM)

Doc. dr. sc. Orhan Jašić - Bosna i Hercegovina (Filozofski fakultet Tuzla)

Prof. dr. sc. Tajana Krička - Hrvatska (Agronomski fakultet Zagreb)

Doc. dr. sc. Dejan Kojić - Bosna i Hercegovina (Univerzitet PIM)

Slobodan Kulić, mag. iur. - Srbija (Srpska ornitološka federacija i Confederation ornitologique mondiale)

Prof. dr. sc. Biljana Lazović - Crna Gora (Biotehnički fakultet Podgorica)

Prof. dr. sc. Branka Ljevnaić-Mašić - Republika Srbija (Poljoprivredni fakultet Univerziteta u Novom Sadu)

Doc. dr. sc. Zvonimir Marijanović - Republika Hrvatska (Kemijsko-tehnološki fakultet u Splitu)

Doc. dr. sc. Ana Matin - Hrvatska (Agronomski fakultet Zagreb)

Prof. dr. sc. Bosiljka Mustać - Hrvatska (Sveučilište u Zadru)

Hrv. akademik prof. dr. sc. Stanislav Nakić - Bosna i Hercegovina (Sveučilište Hercegovina Mostar)

Sandra Popović, mag. ing. - Srbija (Poljoprivredni fakultet Beograd)

Doc. dr. sc. Bojan Simovski - Sjeverna Makedonija (Šumarski fakultet Skopje)

Prof. dr. sc. Davor Skejić - Hrvatska (Građevinski fakultet Zagreb)

Doc. dr. sc. Milan Stanković - Srbija (Univerzitet u Kragujevcu)

Akademik prof. dr. sc. Refik Šećibović - Bosna i Hercegovina (Visoka škola za turizam i menadžment Konjic)

Prof. dr. sc. Andrej Šušek - Slovenija (Fakulteta za kmetijstvo in biosistemske vede Maribor)

Prof. dr. sc. Elma Temim - Bosna i Hercegovina (Agromediteranski fakultet Mostar)

Mr. sc. Merima Toromanović - Bosna i Hercegovina (Biotehnički fakultet Univerziteta u Bihaću)

Doc. dr. sc. Ivana Vitasović Kosić - Hrvatska (Agronomski fakultet Zagreb)

Doc. dr. sc. Ana Vujošević - Srbija (Poljoprivredni fakultet Beograd)

Prof. dr. sc. Vesna Židovec - Hrvatska (Agronomski fakultet Zagreb)

Lektura i grafička priprema: Ančica Sečan Matijaščić, mag. act. soc.

Objavljeno: 31. prosinca 2019. godine.

Časopis izlazi u elektroničkom izdanju dva puta godišnje, krajem lipnja i prosinca, a predviđena su i dva interdisciplinarna specijalna izdanja tijekom godine iz STEM i ostalih znanstvenih/umjetničkih područja.

Časopis je besplatan. Rukopisi i recenzije se ne vraćaju i ne honoriraju.

Umnožavanje (reproduciranje), stavljanje u promet (distribuiranje), priopćavanje javnosti, stavljanje na raspolaganje javnosti odnosno prerada u bilo kojem obliku nije dopuštena bez pismenog dopuštenja Nakladnika.

Sadržaj objavljen u Glasilu Future može se slobodno koristiti u osobne i obrazovne svrhe uz obvezno navođenje izvora. 


\section{Glasilo Future}

\section{Stručno-znanstveni časopis}

FUTURA - stručno-znanstvena udruga za promicanje održivog razvoja, kulture i međunarodne suradnje, Bana Josipa Jelačića 13 a, 22000 Šibenik, Hrvatska

(2019) 2 (3) $01-56$

\section{SADRŽAJ:}

Izvorni znanstveni rad (original scientific paper)

Str.

Zvezda Bogevska, Olga Najdenovska, Marina Stojanova, Monika Stojanova, D. Ristikj

The influence of microbial inoculums on yield and yield components of rocket (Eruca sativa Mill.)

Martina Shotaroska, B. Simovski, T. Nikolovski, Katerina Chonevska, I. Minčev,

V. Stojanovski

Urban Dendroflora of the Macedonia Park in the City of Skopje, North Macedonia

$10-28$

B. Dorbić, Tea Zemunović, Emilija Friganović, Elma Temim, Ž. Španjol, Katica Arar

Stavovi i percepcije kninskih srednjoškolaca o uzgoju i primjeni sobnog bilja

Attitudes and perceptions of the Knin-based secondary school pupils concerning the growing and use of indoor plants

\section{Pregledni rad (scientific review)}

B. Dorbić, A. Uremović, I. Gugić, Emilija Friganović

Ljekovita i uzgojna saznanja o bademu i orahu

Medicinal and breeding knowledge of almond and walnut

$46-54$

Upute autorima (instructions to authors) 
B. Dorbić, Tea Zemunović, Emilija Friganović, Elma Temim, Ž. Španjol, Katica Arar / Stavovi i percepcije kninskih srednjoškolaca o uzgoju i primjeni sobnog... / Glasilo Future (2019) 2 (3) 29-45

\title{
Stavovi i percepcije kninskih srednjoškolaca o uzgoju i primjeni sobnog bilja
}

\section{Attitudes and perceptions of the Knin-based secondary school pupils concerning the}

\author{
growing and use of indoor plants
}

\section{Boris Dorbić $^{1 *}$, Tea Zemunović ${ }^{1,2}$, Emilija Friganović $^{1}$, Elma Temim $^{3}$, Željko Španjol $^{4}$, Katica Arar ${ }^{5}$}

izvorni znanstveni rad (original scientific paper)

doi: $10.32779 /$ gf.2.3.3

\section{Sažetak}

Na osnovu njihovog habitusa, sobno bilje se dijeli na šest skupina: vrste koje izgledom podsjećaju na trave, biljke uspravnog rasta, penjačice i puzavice, rozetaste biljke i loptaste biljke. Unutar općeg dijela ovog rada obrađuju se ekološki i uzgojni zahtjevi sobnog bilja, kao i opća saznanja o njihovim različitim skupinama. Anketno istraživanje provedeno je tijekom mjeseca travnja i svibnja 2018. godine na uzorku od 60 ispitanika (učenika srednje škole) s područja grada Knina, njegove okolice $\mathrm{i}$ susjednih mjesta. Svrha navedenog istraživanja bila je istražiti stavove i percepcije kninskih srednjoškolaca o nabavi, uzgoju i primjeni sobnog bilja. Temeljem anketnog istraživanja ustanovljeno je da ispitanici (učenici kninskih srednjih škola) najviše nabavljaju sobno bilje u vrtnim centrima i supermarketima Knina. Najveći broj ispitanika godišnje izdvoji do 100 kn za nabavu i njegu sobnog bilja. Manji broj ispitanika se često bavi uzgojem lončanica aromatičnog bilja u interijeru. Najvažnija im je ukrasna karakteristika kod sobnog bilja cvijet. Mali broj ispitanika se bavi i uzgojem sobnog bilja. Najveći broj sobnog bilja im se nalazi u dnevnoj sobi. Za uzgoj i njegu sobnog bilja učenike su najviše zainteresirali njihovi roditelji i rodbina.

Ključne riječi: sobno bilje, opća saznanja, učenici, stavovi i percepcije, Knin.

\footnotetext{
Abstract

Based on their habitus, indoor plants are divided into six groups: types whose appearance reminds of grasses, plants that grow vertically, climbers and creepers, rosette-shaped and ball-shaped plants. Ecological and growth requirements of indoor plants have been addressed in the general part of this

${ }^{1}$ Veleučilište "Marko Marulić" u Kninu, Petra Krešimira IV 30, 22300 Knin, Republika Hrvatska.

*E-mail: bdorbic@veleknin.hr

${ }^{2}$ Studentica prediplomskog stručnog studija Poljoprivreda krša - Biljna proizvodnja

${ }^{3}$ Univerzitet Džemal Bijedić u Mostaru, Agromediteranski fakultet, Univerzitetski kampus BB, 88000 Mostar, Bosna i Hercegovina.

${ }^{4}$ Sveučilište u Zagrebu, Šumarski fakultet, Svetošimunska c. 25, 10000 Zagreb, Republika Hrvatska

${ }^{5}$ Sveučilište u Mostaru, Agronomski i prehrambeno tehnološki fakultet Mostar, Biskupa Čule BB, 88000 Mostar, Bosna i Hercegovina.
} 
B. Dorbić, Tea Zemunović, Emilija Friganović, Elma Temim, Ž. Španjol, Katica Arar / Stavovi i percepcije kninskih srednjoškolaca o uzgoju i primjeni sobnog... / Glasilo Future (2019) 2 (3) 29-45

paper and general knowledge is provided about their different groups. A survey research was conducted in April and May 2018 on a sample of 60 respondents (secondary school pupils) from the area of the city of Knin, its outskirts and the neighbouring towns. The specific objective of the previously mentioned research was to analyse attitudes and perceptions of the Knin-based secondary school pupils in terms of supply, growing and use of indoor plants. According to the findings of the survey research, it was concluded that the respondents (the Knin-based secondary school pupils) most frequently purchase indoor plants in the Knin-based garden centres and supermarkets. The largest number of the respondents spend up to HRK100 at an annualised level for the purchase and care for indoor plants. A smaller number of the respondents are frequently involved in growing of potted aromatic herbs indoors. The decorative feature of indoor plants that they pointed out as the most important for them is the flower. A small number of the respondents are also involved in growing of indoor plants. The respondents normally place the largest number of indoor plants in the living room. The secondary school pupils' parents and relatives played the most important role in terms of arousing their interest in growing and care for indoor plants.

Key words: indoor plants, general knowledge, pupils, attitudes and perceptions, Knin.

\section{Uvod}

Ljudi su još davnina uzgajati različite sobne biljne vrste. Svojim rastom i razvojem u interijerima sobno bilje pruža lijep ugođaj ne samo izgledom već ponekad i mirisom (Courtier i Clarke, 1997).

Danas je urbanizirani način života doveo do toga da ljudi $80 \%$ ili više vremena provode u zatvorenim prostorima (Fjeld et al., 1998., prema Doxey et al., 2009.). Mnogi pojedinci i tvrtke oplemenjuju svoje domove ili urede sobnim biljem (Dravigne et al., 2008., prema Doxey et al., 2009).

Sobno bilje se na osnovu habitusa dijeli na šest skupina: vrste koje svojim izgledom podsjećaju na trave, biljke uspravnog rasta, penjačice i puzavice, rozetaste biljke i loptaste biljke. Sobne biljke koje izgledom podsjećaju na trave imaju busenast rast i duge uske listove. Biljke uspravna rasta često se koriste kao soliterne biljke. Ovoj skupini pripadaju neki kaktusi, stablašice i vrste kod kojih habitus ima oblik palme (Temim i Dorbić, 2017).

Prije početka uzgoja sobnog bilja potrebno je odabrati posude za njihov uzgoj. Posude za biljke mogu biti: glineni lonci, ukrasne posude, čaše, školjke, žardinijere, zdjele, vaze, košare itd. Odabirom oblika i veličine posude pospješuje se kvaliteta razvoja biljke te o njoj kao i o ishrani ovisi razvoj njezina korijena (Courtier i Clarke 1997). 
B. Dorbić, Tea Zemunović, Emilija Friganović, Elma Temim, Ž. Španjol, Katica Arar / Stavovi i percepcije kninskih srednjoškolaca o uzgoju i primjeni sobnog... / Glasilo Future (2019) 2 (3) 29-45

Da bi biljci omogućili da razvije stabilan korijenov sustav, lonac mora biti odgovarajućih dimenzija, zatim mora sadržavati dovoljno komposta radi opskrbe hranjivih tvari i vode, i imati drenažne otvore kako bi se omogućilo otjecanje suvišne vode iz komposta (Courtier i Clarke, 1997).

Posude za uzgoj sobnog bilja mogu biti od različitih materijala kao što su: keramika, staklo, plastika, metal, glina, beton itd.

Začinske biljke zauzimaju posebno mjesto kao sobne biljke. Neke od njih su jednogodišnje, pa ih je potrebno svake godine ponovno sijati. Kao sobno začinsko bilje najviše se uzgajaju: krasuljica, vlasac, mažuran, bosiljak, peršin, majčina dušica, ružmarin i čubar (Squire, 1996).

Prilikom odabira bilja za interijer bitno je naglasiti da pojedine biljne vrste nisu uvijek u "modi" kao $i$ da postoje različiti stavovi ljudske populacije o odabiru (Dorbić et al., 2018).

Interes za bilje, posebno za ukrasno imaju i djeca i stariji adolescenti. Osim vlastitih sklonosti koje pojedinac treba uglavnom pokazivati njegova okolina (u smislu društvene interakcije) također može pridonijeti u profiliranju i produbljenju interesa. Tako su npr. značajnu ulogu u organizaciji slobodnog vremena tijekom XIX. stoljeća u zadarskim učiteljskim preparandijama imali i školski vrtovi u kojima su učenici pomagali vrtlaru obrađivati vrt (Ströll, 1900). Rad u vrtu trebao ih je odmaknuti od mehaničkog učenja u zatvorenoj prostoriji (Vigato, 2008).

I u hrvatskoj nalazimo na slično, gdje se u projektu "Najljepši školski vrtovi" koji je započeo školske godine 1994./95., radilo na obnovi školskih vrtova, u kojima bi djeca baveći se vrtlarenjem lakše prebrodila ratne traume.

Neka su istraživanja u svijetu pokazala da sobno bilje pozitivno djeluje na umanjenje nedoličnog ponašanja i izostanke kod učenika osnovne škole ukoliko su s njim oplemenjene učionice (Ke-Tsung Han, 2008).

Sobno bilje može utjecati na čovjekovu psihu, poput smanjene napetosti (Ulrich et al., 1991., prema Doxey et al., 2009), te povećanu sposobnost koncentracije i pažnje (Taylor et al., 2001., prema Doxey et al., 2009).

$\mathrm{Na}$ osnovama navedenog provest će se anketno istraživanje gdje će se istražiti stavovi i percepcije kninskih srednjoškolaca o njihovoj nabavi, uzgoju i primjeni sobnog bilja.

\section{Materijali i metode}

Prilikom izrade ovog rada kao izvor podataka koristila se stručna i znanstvena literatura. Kao izvor primarnih podataka obavljeno je anketno istraživanje na području grada Knina. 
B. Dorbić, Tea Zemunović, Emilija Friganović, Elma Temim, Ž. Španjol, Katica Arar / Stavovi i percepcije kninskih srednjoškolaca o uzgoju i primjeni sobnog... / Glasilo Future (2019) 2 (3) 29-45

Cilj provođenja anketnog ispitivanja na području grada Knina i njihove okolice bilo je istražiti stavove i percepcije kninskih srednjoškolaca, maturanata Srednje škole Lovre Montija o njihovoj nabavi, uzgoju i primjeni sobnog bilja.

Anketno istraživanje provedeno je tijekom mjeseca travnja i svibnja 2018. godine na uzorku od 60 ispitanika. U pogledu boravišta ispitanika s područja grada Knina je bilo 42 ispitanika, okolice Knina 16 ispitanika i ostalih mjesta 2 ispitanika. Među ispitanicima se nalazilo 38 žena i 22 muškarca. Starosna struktura uzorka bila je od 18 do 20 godina.

Statistička obrada podataka je izvršena u programu SPSS 14 za Windows sučelje.

\section{Ekološki zahtjevi sobnog bilja}

\section{Temperatura}

Većina sobnog bilja potječe iz tropskih krajeva. Temperatura je važan čimbenik u aktivaciji rasta biljke te mora biti u ravnoteži sa količinom i jačinom sunčeve svjetlosti (Squire, 1996).

U predsoblju, spavaćoj sobi i hodniku prevladavaju svježi uvjeti što pogoduje uspješniji rast većih biljaka. Stalna temperatura veća od $20{ }^{\circ} \mathrm{C}$ nepovoljno utječe na gotovo sve vrste sobnog bilja. Uz pravilno osvjetljenje tropske biljke podnose sobnu temperaturu od $35^{\circ} \mathrm{C}$, dok temperatura veća od $44{ }^{\circ} \mathrm{C}$ nepovoljno utječe na sve sobne biljke. Tijekom zime potrebe sobnog bilja za temperaturom su manje jer većina njih ulazi u fazu mirovanja (Herwig, 1975).

Kako bi biljka tijekom svog rasta i razvoja bila vitalna, svijetlost, temperatura i vlaga moraju biti u stalnoj ravnoteži (Squire, 1996).

\section{Svjetlost}

Svjetlost je značajan faktor za pravilan rast i razvoj sobnog bilja. Utjecaj i količina svjetla koja utječe na razvoj biljke ovisi o: veličini i položaju prozora, godišnjem dobu, vremenskim prilikama, o drveću ili zgradama te o zahtjevima svake pojedine biljke za svjetlošću (Courtier i Clarke, 1997).

Prema količini svjetla koja je potrebna različitim vrstama razlikuje se: puna sunčevu svjetlost, lagana sjenu, sjena i duboka sjena. Najpogodnije vrste za svijetle prozorske daske su kaktusi, kojima sunčeva svjetlost najviše odgovara prije i tijekom cvatnje. Tako npr. Amarilis (Hipeastrum) i neke druge vrste preferiraju svjetlo za vrijeme cvatnje: Echinocereus pectinatus, Aporocactus flagelliformis, lithops salicola i Lithops pseudotrutancella (Squire, 1996). 
B. Dorbić, Tea Zemunović, Emilija Friganović, Elma Temim, Ž. Španjol, Katica Arar / Stavovi i percepcije kninskih srednjoškolaca o uzgoju i primjeni sobnog... / Glasilo Future (2019) 2 (3) 29-45

Afrička ljubica (Saintpaulia ionantha), Euphorbia pulcherrima, Sanservieria trifasciata i Zebrina pendula su vrste koje zahtijevaju izrazito sunčevo osvjetljenje, pa ih je najbolje smjestiti kod osvijetljenog prozora (Squire, 1996).

\section{Voda i vlažnost zraka}

Voda je sastavni dio svake biljke. Potrebe za vodom razlikuju se kod svake biljne vrste po na osob. Količina vode ovisi o godišnjem dobu i mikroklimatskim uvjetima unutar sobe u kojoj se biljka nalazi (Squire, 1996).

Najbolji pokazatelj dali biljka ima dovoljno vode je zemlja, koju je najbolje održavati podjednako vlažnom. Također venuće biljke ukazuje i na prekomjerni sadržaj vode pa korijen biljke često trune. Količina vode ovisi o veličini biljke i posude u kojoj se ona nalazi (Squire, 1996). Biljke se mogu zalijevati: kišnicom, odstajalom vodom te vodom iz gradskog vodovoda (Hessayon, 2002). Temperatura vode kojom zalijevamo biljke također je vrlo bitna, da ne dođe do stresa (Squire, 1996). Biljke tijekom zimskog mirovanja traže manje vode, dok su ljeti potrebe za vodom puno veće (Larousse, 2001).

\section{Supstrat}

Za supstrat se mogu koristiti različiti materijali prirodnog podrijetla kao što su: pijesak, treset, kućni kompost, kore od stabla i kokosova vlakna. Kao kompost može se koristiti i vrtna zemlja, ali ona sadrži dosta manje hranjiva. Zbog svoje prekompaktne strukture vrtna se zemlja miješa s raznim materijalima, te se kao takva koristi za sadnju velikih biljaka kao što su: palme, fikusi, agrumi, dracene itd. (Larousse, 2001).

Kompostu se najčešće dodaje riječni pijesak ili vrtlarski šljunak kako bi mu se poboljšala drenaža. Za razliku od pijeska, treset je lakši i čišći te dobro zadržava vlagu, ali mu je glavni nedostatak što sadrži malo hranjivih tvari (Bland i Davidson, 2002).

Većina biljnih vrsta ne preferira istu zemlju za uzgoj. Neke biljke vole kiselija tla koja su obogaćena humusom, dok druge više preferiraju vapnenasto-poroznu zemlju (Herwig, 1975).

Danas postoje specijalne mješavine i komposti tzv. sintetički jer u sebi sadržavaju materijale koji nisu organskog podrijetla. Najčešće se u tako kupljenim mješavinama nalaze materijali koji poboljšavaju zrak i drenažu (Larousse, 2001).

Najčešće korišteni sintetički materijali su perlit i vermikulit. Perlit se zbog svoje male težine koristi kao zamjena za pijesak, i njegova jedina uloga je zračenje. Vermikulit se radi od gline uz pomoć visoke temperature. Odličan je element za zračenje i drenažu jer ne zadržava vlagu. 
B. Dorbić, Tea Zemunović, Emilija Friganović, Elma Temim, Ž. Španjol, Katica Arar / Stavovi i percepcije kninskih srednjoškolaca o uzgoju i primjeni sobnog... / Glasilo Future (2019) 2 (3) 29-45

Danas postoji kompost za lisnate biljke, kaktuse, agrume, orhideje i za bonsai (Larousse, 2001).

\section{Mjere njege i održavanja sobnog bilja}

Pod njegom sobnog bilja podrazumjeva se prihranjivanje, zalijevanje, presađivanje, privikavanje, podupiranje, skidanje ocvalih cvjetova.

\section{Prihranjivanje}

Kako bi uzgajane biljke imale dobar rast i razvoj potrebno im je osigurati dovoljno hranjivih tvari. Najjednostavniji način ishrane kućnih biljaka je dodavanje gnojiva u vodu. Kod jako neishranjenih biljaka koristi se i foliarna gnojidba (Matrin, 1986).

Hranjiva za kućne biljke dijele se na hranjiva za lisnate biljke (s visokim udjelom dušika) i na hranjiva za cvatuće biljke (s visokim udjelom kalija). Hranjiva se mogu nabaviti u raznim oblicima: u granulama, kao tekuće ili praškasto gnojivo, kao tablete i štapići hranjiva te kao folijarna hranjiva (Courtier i Clarke, 1998).

\section{Presađivanje}

Presađivanje biljaka se obavlja kada one istroše sva hranjiva i kada prerastu posudu u kojoj su prvotno rasle. Korijenje koje izlazi iz dna lonca znak je da ju treba presaditi. Biljka se presađuje u nešto veći lonac od prethodnog. Najbolje je da se presađivanje obavi početkom razdoblja aktivnog rasta. Neke kučne biljke je potrebno više puta godišnje presađivati (Matrin, 1986).

\section{Adaptacija}

Pod privikavanje spadaju uzgojni zahvati vezivanje biljaka uz potporanj, otkidanje i podrezivanje te otkidanje mrtvih osušenih glavica cvjetova.

Biljke kao što su penjačice zahtjevaju potporanj uz koji će se moći penjati, te neke od njih imaju zračno korijenje koje zahtjeva vlažnu površinu.

Mnogim kućnim biljkama prilikom uzgoja nije potrebno otkidanje ili podrezivanje, ali mnoge od njih treba orezivati kako bi im se sačuvao uzgojni oblik. Uklanjanjem vrha stabljike postiže se da biljka ne ide previše u visinu, te se postiže rast pupova u pazušcima listova.

Nakon cvatnje vrlo je poželjno ukloniti stare ocvale cvjetove jer oni narušavaju izgled biljke. Ako ih se ne ukloni na vrijeme biljka gubi energiju stvarajući sjeme (Courtier i Clarke, 1998) 
B. Dorbić, Tea Zemunović, Emilija Friganović, Elma Temim, Ž. Španjol, Katica Arar / Stavovi i percepcije kninskih srednjoškolaca o uzgoju i primjeni sobnog... / Glasilo Future (2019) 2 (3) 29-45

\section{Rezultati i diskusija}

Svrha anketnog istraživanja bila je ispitati stavove i percepcije kninskih srednjoškolaca o nabavi, uzgoju i primjeni sobnog bilja (Slike 1. - 4., 5. - 15., 16. - 20.).

Slike 1. - 4. Istraživanje stavova i mišljenja kninskih srednjoškolaca o nabavi i izboru sobnog bilja (prema Zemunović, 2018)

Figures 1 - 4. Attitudes and perceptions of the Knin-based secondary school pupils concerning on the procurement and selection of houseplants (according to Zemunović, 2018)
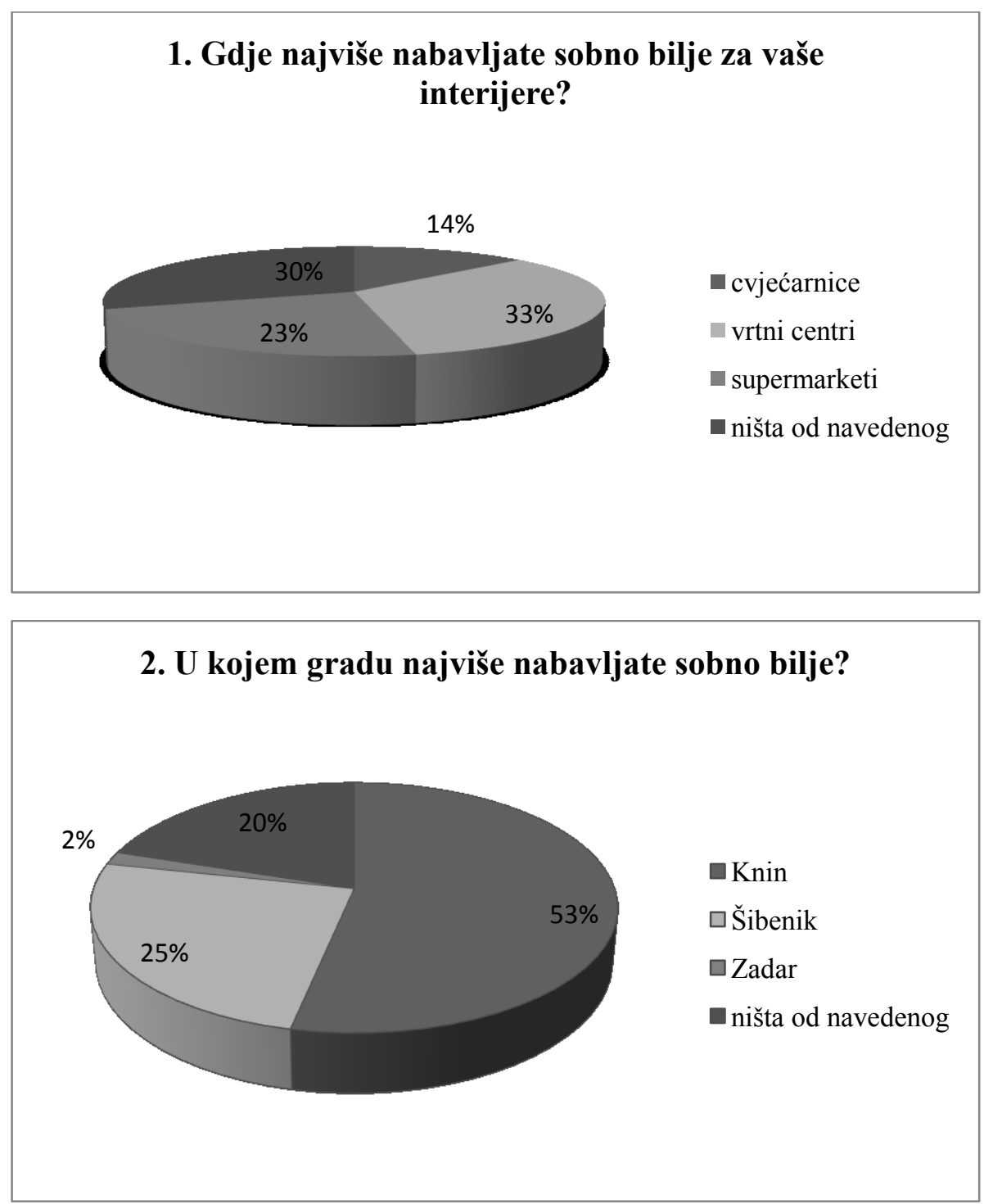
B. Dorbić, Tea Zemunović, Emilija Friganović, Elma Temim, Ž. Španjol, Katica Arar / Stavovi i percepcije kninskih srednjoškolaca o uzgoju i primjeni sobnog... / Glasilo Future (2019) 2 (3) 29-45
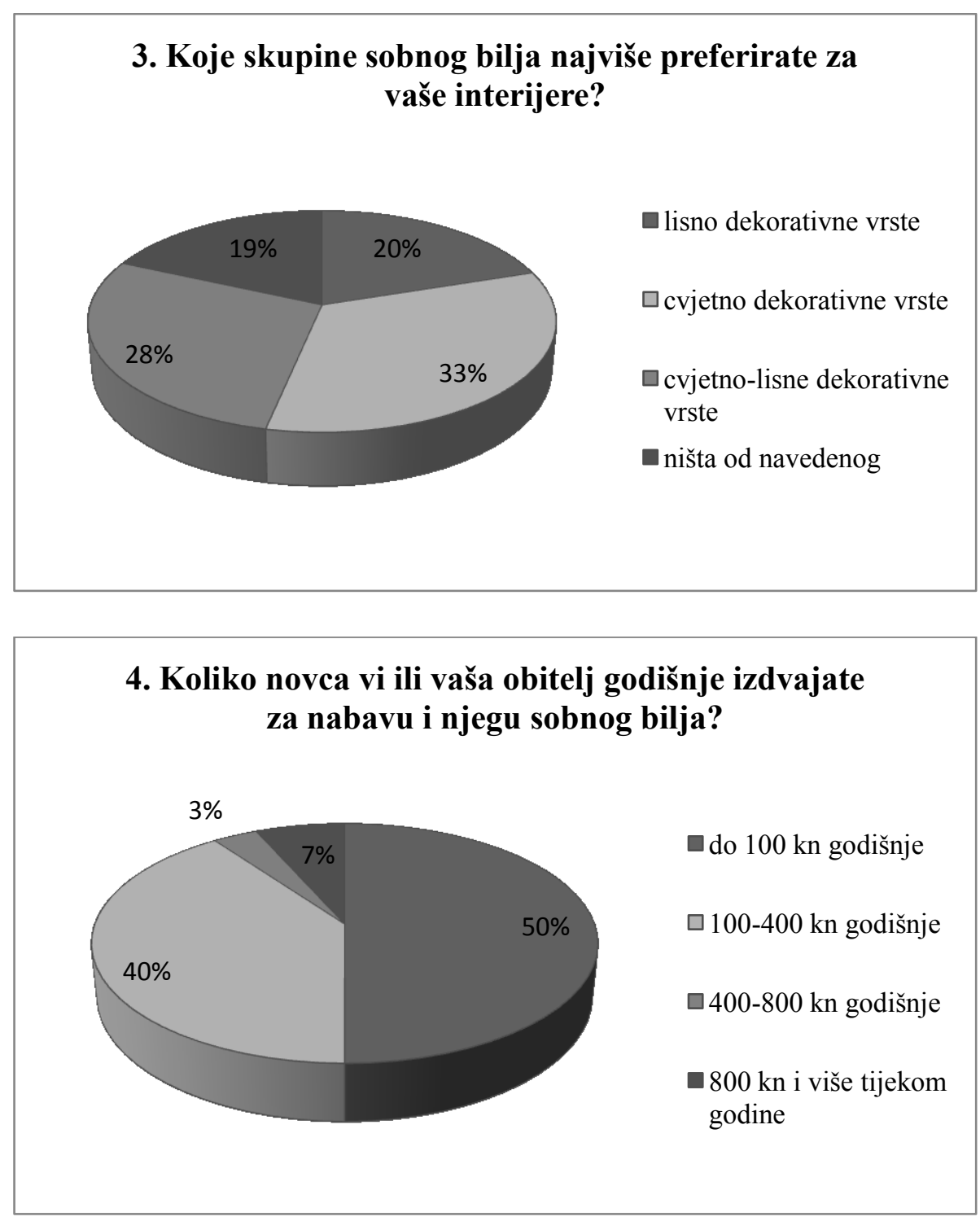

Iz slika 1. - 4. je razvidno da ispitanici najviše nabavljaju sobno bilje u vrtnim centrima $\mathrm{i}$ supermarketima (33,3 \% i 23,3 \%). Njih 53,3 \% nabavlja sobno bilje u gradu Kninu. Za sobne interijere najviše preferiraju cvjetno dekorativne i cvjetno-lisne dekorativne vrste (33,3 \% i 28,3\%). $50,0 \%$ ispitanika godišnje izdvoji do $100 \mathrm{kn}$ za nabavu i njegu sobnog bilja, a njih 40,0 \% od 100 do 400 kn godišnje.

Slike 5. - 15. prikazuju stavove i mišljenja kninskih srednjoškolaca o uzgoju i vrstama sobnog bilja. Na pitanje bavite li se uzgojem lončanica aromatičnog bilja u vašem interijeru, $(21,7 \%)$ ispitanika je odgovorilo da to radi često, a njih (36,7\% ) nikada (Slika 5.).

46,7\% ispitanika u inerijeru nije posjedovalo patuljasto drveće "Bonsai". Ispitanici su posjedovali kaktuse i sukulente (40,0 \%). Veći broj ispitanika (68,3\%) nije posjedovao male terarije ili staklene vrtove (vrtovi u boci) sa sobnim biljem. Nešto više od polovine ispitanika $(56,7 \%)$ nije posjedovao zatvoreni (ostakljeni) balkon u kojem je uzgajao sobno bilje. Na pitanje "Koja je po vama najvažnija 
B. Dorbić, Tea Zemunović, Emilija Friganović, Elma Temim, Ž. Španjol, Katica Arar / Stavovi i percepcije kninskih srednjoškolaca o uzgoju i primjeni sobnog... / Glasilo Future (2019) 2 (3) 29-45

ukrasna karakteristika sobnog bilja?" 53,3 \% ispitanika se odlučilo za cvjetove, a 26,7 \% za listove. Ispitanici, njih $40 \%$, uzgajaju do 5 biljaka, a 28,3 \% između 5 do 10 biljaka. Vezano za pitanje o pridržavanju ekoloških principa kod uzgoja i njege sobnog bilja, najveći broj ispitanika (43,3 \%) je odgovorio da to radi osrednje. Keramičke (45,0 \%) i plastične $(31,7 \%)$ dekorativne lonce ispitanici najviše koriste za sobno bilje. Uglavnom nikada (46,7 \%) i rijetko se u slobodno vrijeme bave razmnožavanjem sobnog bilja. Mali broj ispitanika se bavi i uzgojem sobnog bilja, samo njih (23,3 \%) to čini često, a (45,0 \%) rijetko.

Slike 5. - 15. Istraživanje stavova i mišljenja kninskih srednjoškolaca o uzgoju i vrstama sobnog bilja (prema Zemunović, 2018)

Figures 5 - 15. Attitudes and perceptions of the Knin-based secondary school pupils concerning the growing and species of indoor plants (according to Zemunović, 2018)
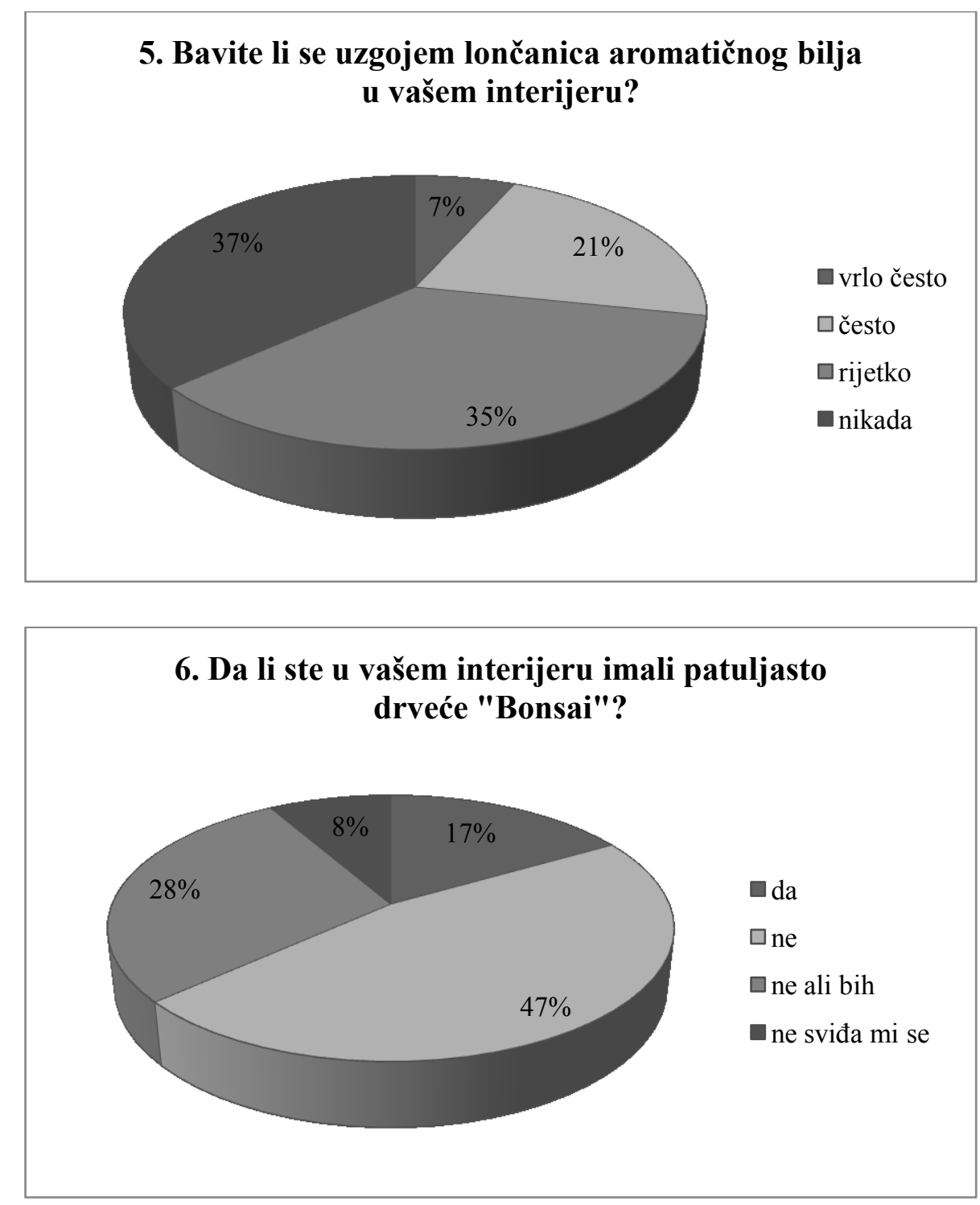
B. Dorbić, Tea Zemunović, Emilija Friganović, Elma Temim, Ž. Španjol, Katica Arar / Stavovi i percepcije kninskih srednjoškolaca o uzgoju i primjeni sobnog... / Glasilo Future (2019) 2 (3) 29-45

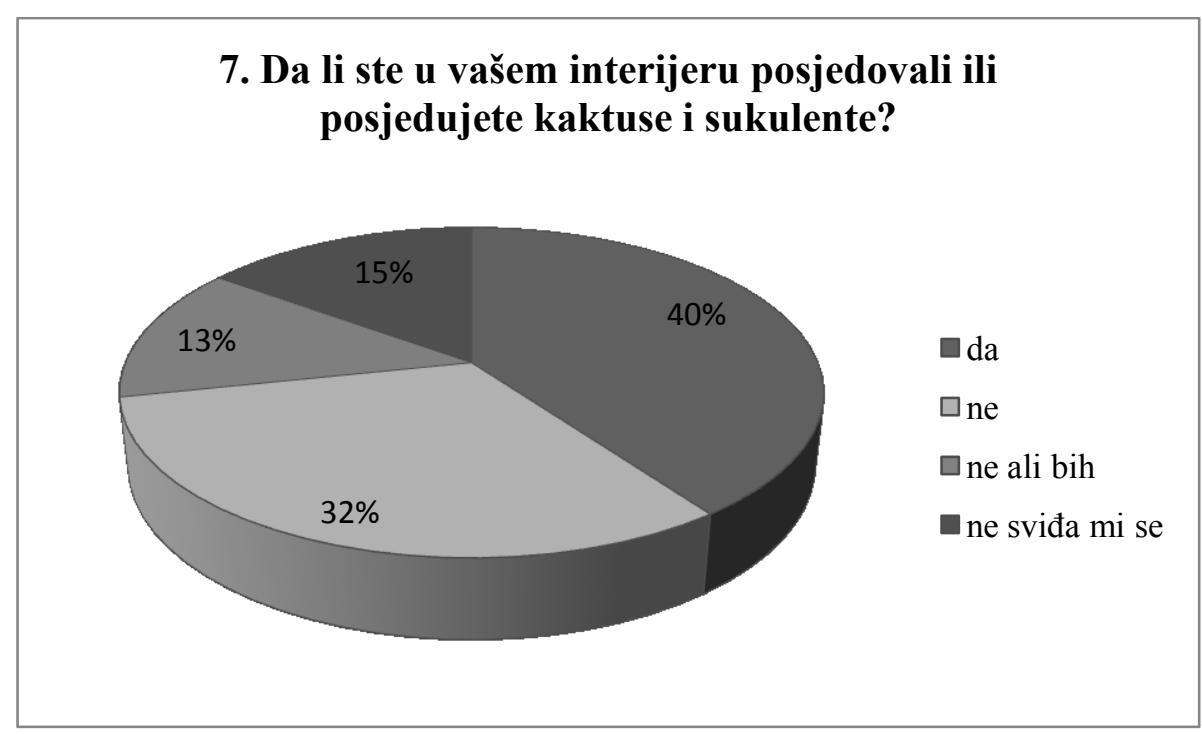

8. Da li ste u vašem interijeru imali male terarije ili staklene vrtove (vrtovi u boci) sa sobnim biljem ?

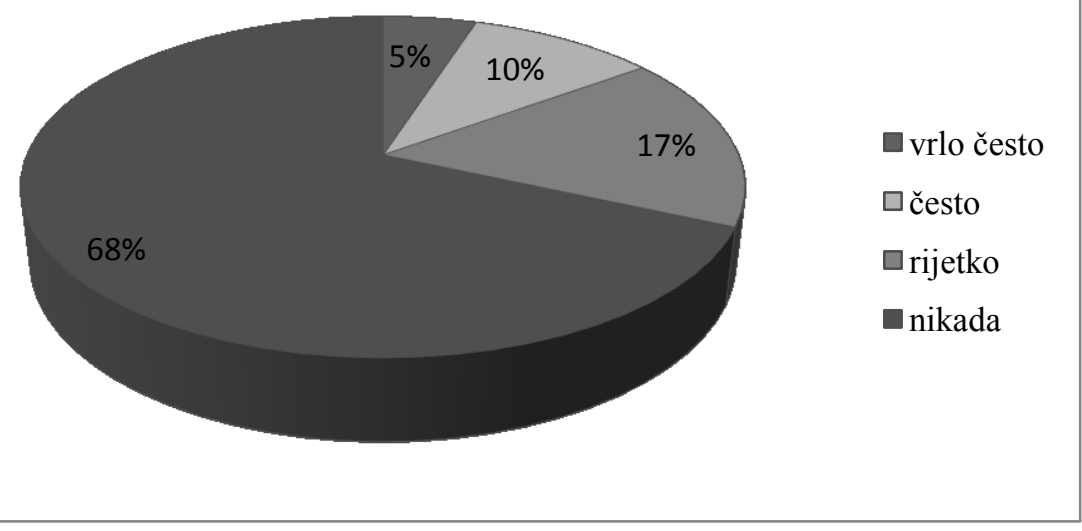

\section{Da li posjedujete zatvoreni (ostakljeni) balkon u} kojem uzgajate sobno bilje?

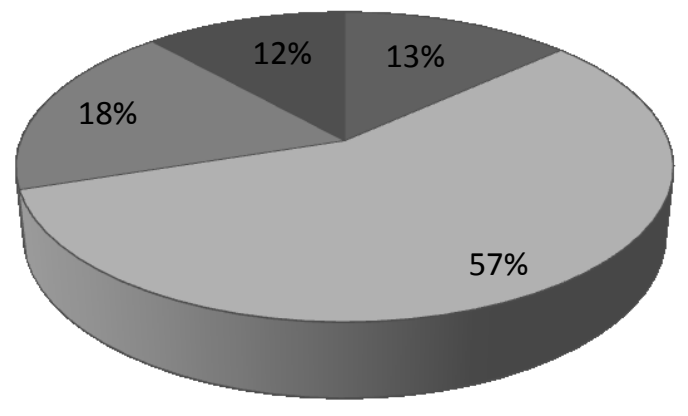

$\square \mathrm{da}$

$\square$ ne

$\square$ ne ali bih volio/la

口ne sviđa mi se 
B. Dorbić, Tea Zemunović, Emilija Friganović, Elma Temim, Ž. Španjol, Katica Arar / Stavovi i percepcije kninskih srednjoškolaca o uzgoju i primjeni sobnog... / Glasilo Future (2019) 2 (3) 29-45
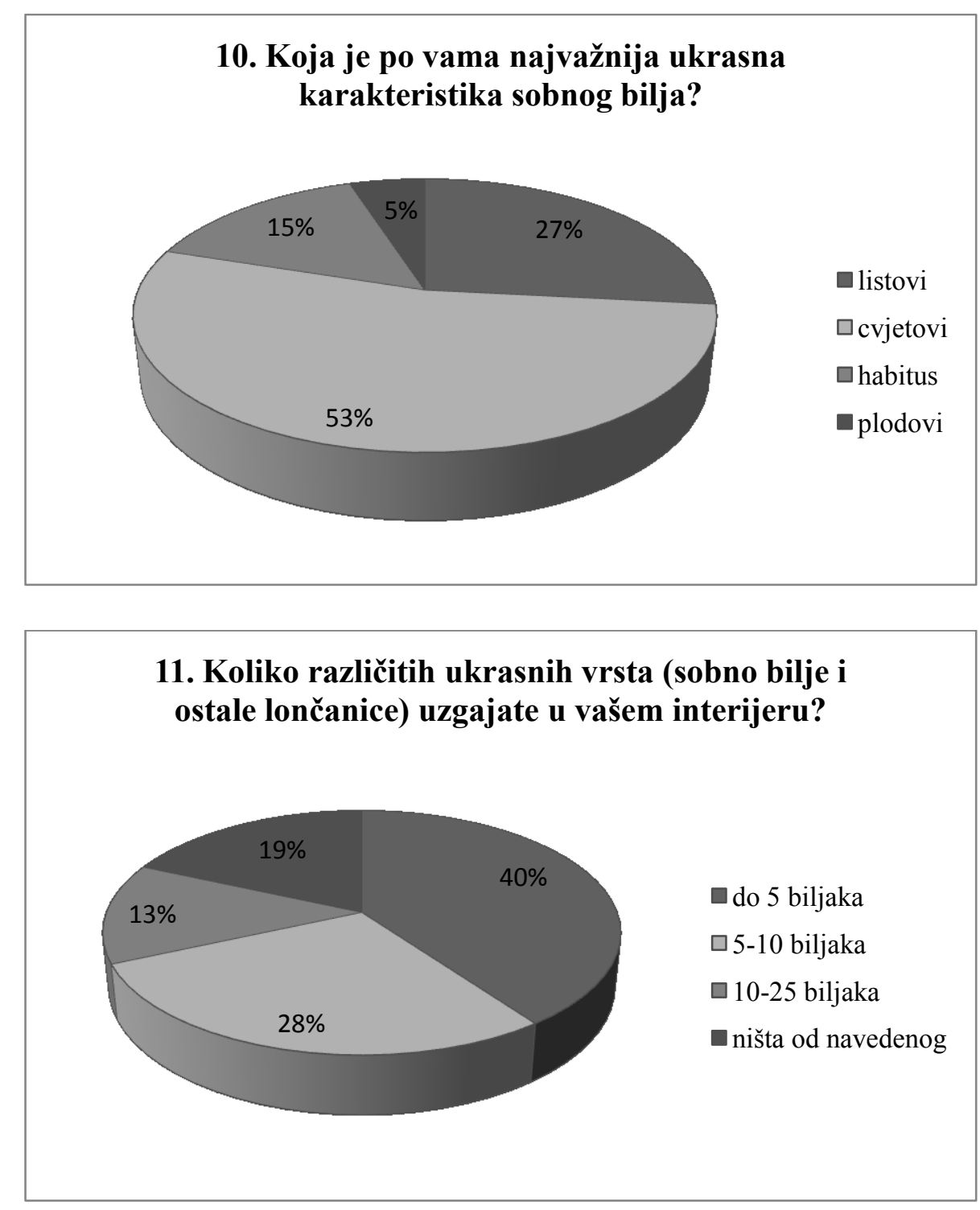

12. Da li se pridržavate ekoloških principa kod uzgoja i njege sobnog bilja?

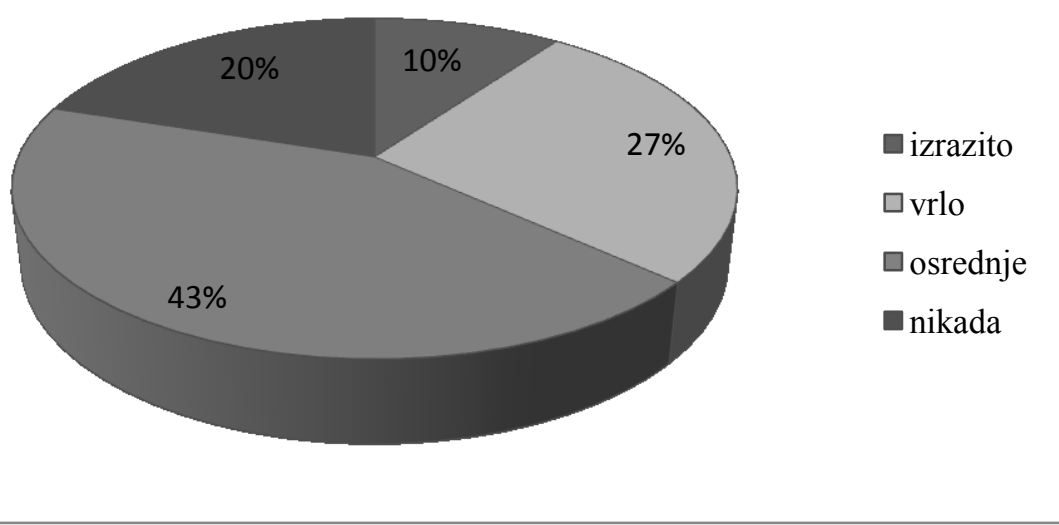


B. Dorbić, Tea Zemunović, Emilija Friganović, Elma Temim, Ž. Španjol, Katica Arar / Stavovi i percepcije kninskih srednjoškolaca o uzgoju i primjeni sobnog... / Glasilo Future (2019) 2 (3) 29-45
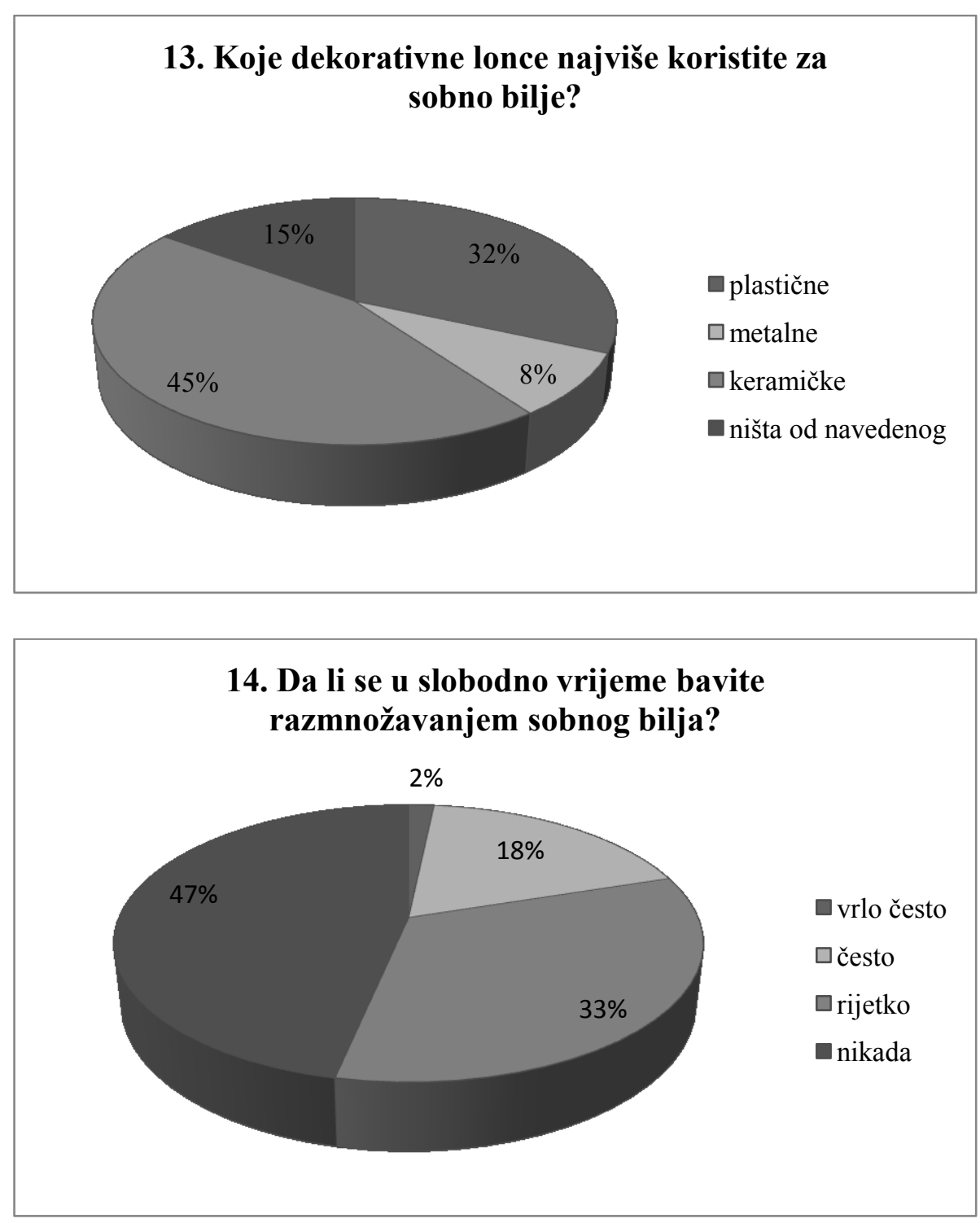

15. Koliko se često bavite uzgojem sobnog bilja?

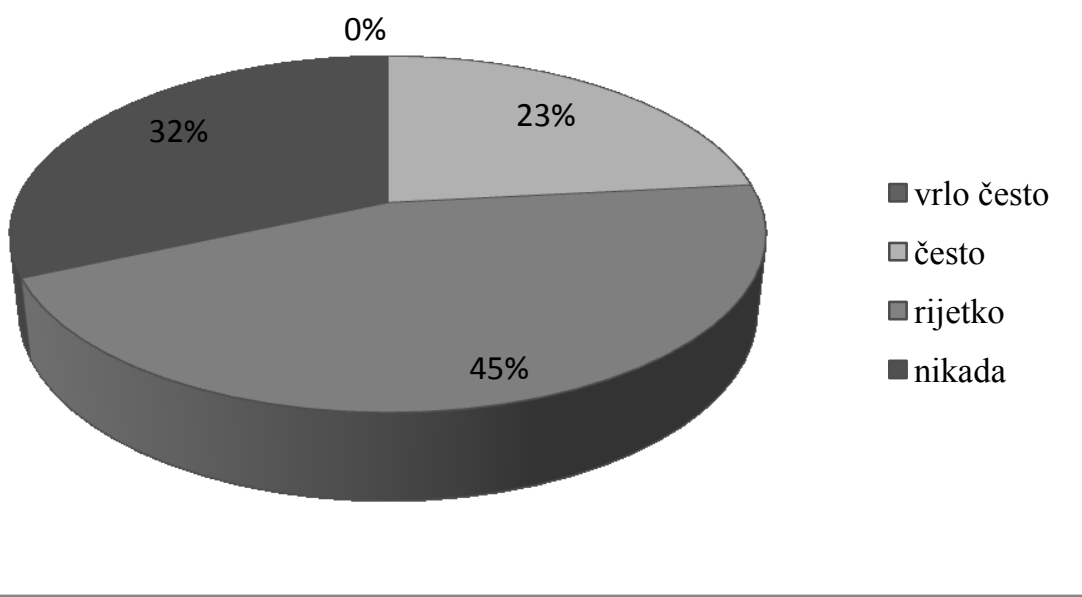


B. Dorbić, Tea Zemunović, Emilija Friganović, Elma Temim, Ž. Španjol, Katica Arar / Stavovi i percepcije kninskih srednjoškolaca o uzgoju i primjeni sobnog... / Glasilo Future (2019) 2 (3) 29-45

Iz slika 16. - 20. koje prikazuju stavove i mišljenja kninskih srednjoškolaca o primjeni i njezi sobnog bilja razvidno je da uzgoj ili promatranje sobnog bilja u interijeru tek osrednje $(31,7 \%)$ i malo $(30,0$ \%) utječe na bolje raspoloženje ispitanika. Najveći broj ispitanika $(35,0 \%)$ je osrednje i malo zadovoljno s uređenjem stambenog prostora sa sobnim biljem. U pogledu mjera njege kod uzgoja najviše ih zanimaju zalijevanje i prihrana (46,7 \%) i ostale mjere njege (23,3\%). Najveći broj sobnog bilja im se nalazi u dnevnoj sobi (66,7 \%). Za uzgoj i njegu sobnog bilja su ih najviše zainteresirali roditelji i rodbina $(55,0 \%)$.

Slike 16. - 20. Istraživanje stavova i mišljenja kninskih srednjoškolaca o primjeni i njezi sobnog bilja (prema Zemunović, 2018)

Figures 16-20. Attitudes and perceptions of the Knin-based secondary school pupils concerning the use and care species of indoor plants (according to Zemunović, 2018)

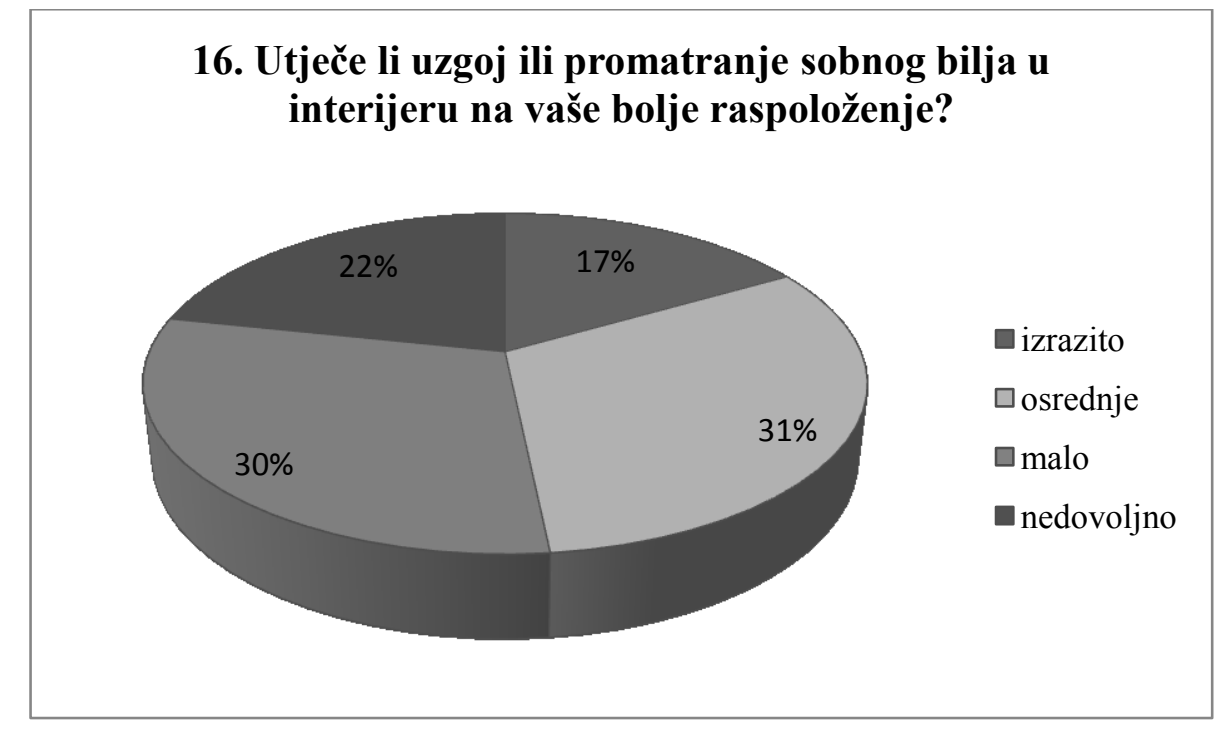

\section{Da li ste zadovoljni uređenjem vašeg stambenog prostora sa sobnim biljem?}

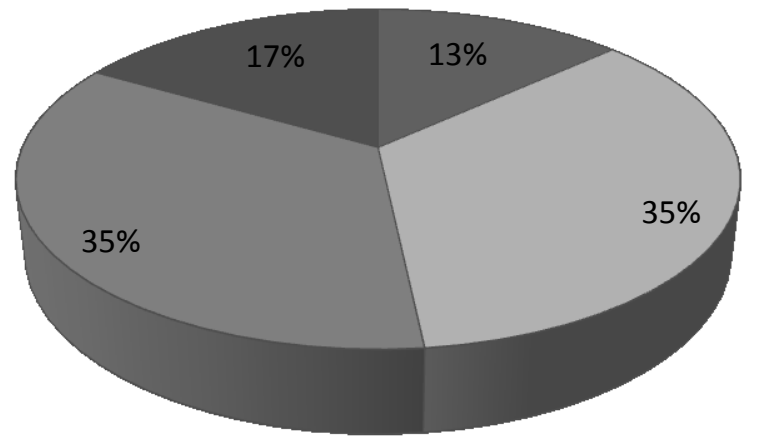


B. Dorbić, Tea Zemunović, Emilija Friganović, Elma Temim, Ž. Španjol, Katica Arar / Stavovi i percepcije kninskih srednjoškolaca o uzgoju i primjeni sobnog... / Glasilo Future (2019) 2 (3) 29-45
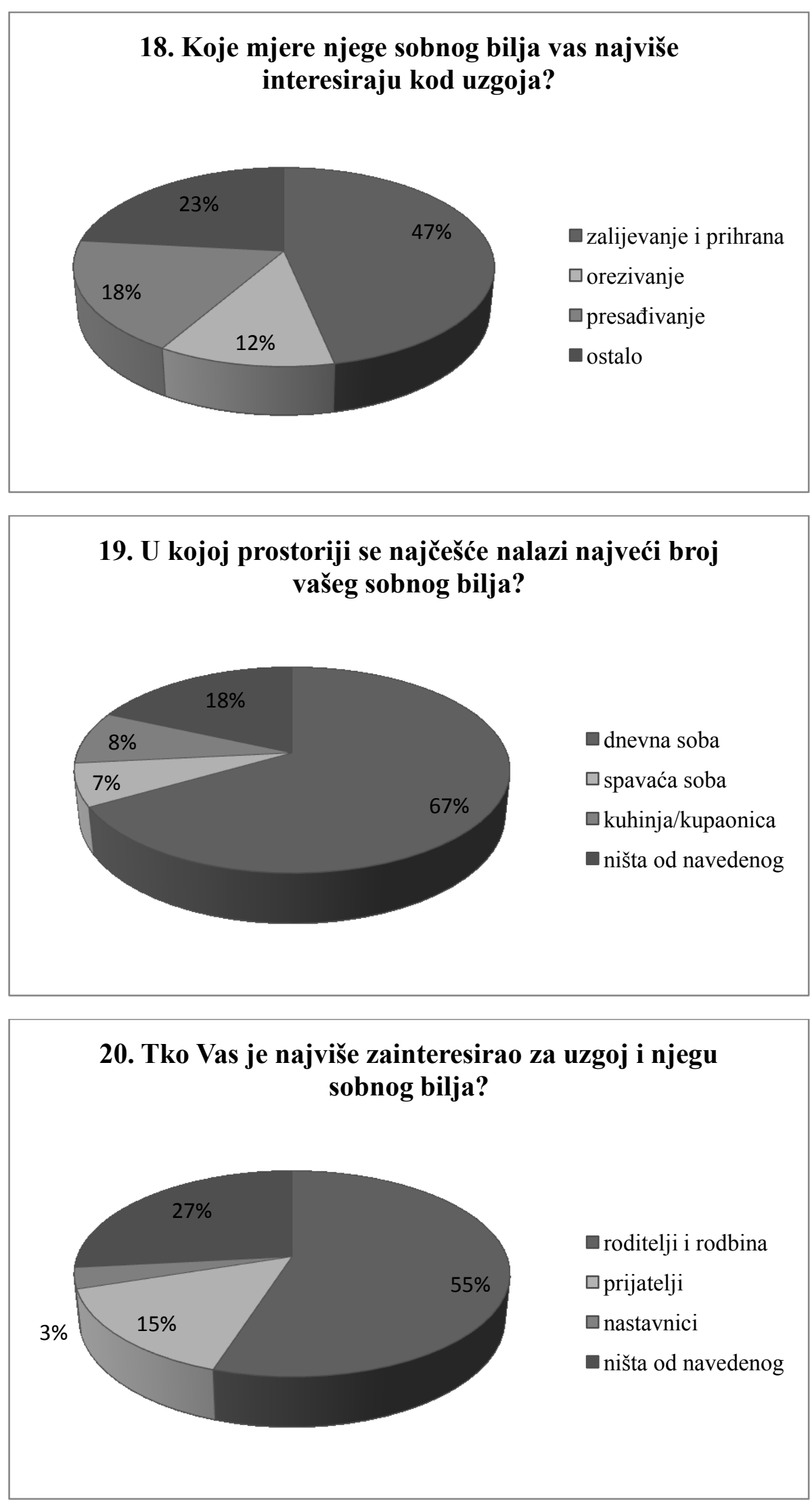
B. Dorbić, Tea Zemunović, Emilija Friganović, Elma Temim, Ž. Španjol, Katica Arar / Stavovi i percepcije kninskih srednjoškolaca o uzgoju i primjeni sobnog... / Glasilo Future (2019) 2 (3) 29-45

\section{Zaključak}

Temeljem anketnog istraživanja ustanovljeno je da ispitanici (učenici kninske srednje škole "Lovre Montija") najviše nabavljaju sobno bilje u vrtnim centrima i supermarketima u gradu Kninu. Za sobne interijere najviše preferiraju cvjetno dekorativne i cvjetno-lisne dekorativne vrste.

50 \% ispitanika godišnje izdvoji do 100 kn godišnje za nabavu i njegu sobnog bilja što ne predstavlja značajan iznos, moglo bi se reći da je iznos vrlo mali.

Manji broj ispitanika se često bavi uzgojem lončanica aromatičnog bilja u interijeru. 40 \% učenika je posjedovalo kaktuse i sukulente. Nešto više od polovine ispitanika (56,7 \%) nije posjedovao zatvoreni (ostakljeni) balkon u kojem je uzgajao sobno bilje.

Ispitanici kao najvažniju ukrasnu karakteristiku kod sobnog bilja navode cvijet.

Najveći broj ispitanika uzgaja do pet biljaka i osrednje se pridržavaju ekoloških principa uzgoja i njege sobnog bilja. Gotovo nikada i rijetko se u slobodno vrijeme bave razmnožavanjem sobnog bilja. Mali broj ispitanika se bavi i uzgojem sobnog bilja.

Ustanovljeno je i da uzgoj ili promatranje sobnog bilja u interijeru tek osrednje i malo utječe na njihovo bolje raspoloženje. Najveći broj ispitanika je osrednje i malo zadovoljno s uređenjem stambenog prostora sa sobnim biljem. U pogledu mjera njege kod uzgoja ih najviše zanimaju zalijevanje i prihrana $(46,7 \%)$.

Najveći broj sobnog bilja ispitanici drže u dnevnoj sobi. Za uzgoj i njegu sobnog bilja su ih najviše zainteresirali roditelji i rodbina.

\section{Zahvala}

Rad je nastao u okviru izrade Završnog rada, diplomantice Teje Zemunović na Veleučilištu "Marko Marulić" u Kninu, 2018. godine: Stavovi i percepcije kninskih srednjoškolaca o uzgoju i primjeni sobnog bilja.

\section{Literatura}

Bland, J., Davidson, W. (2002). Kućne biljke. Rijeka: Dušević i Kršovnik d.o.o.

Courtier, J., Clarke, G. (1997). Sve o kućnim biljkama. Rijeka: Dušević i Kršovnik d.o.o.

Dorbić, B., Temim, E. (2017). Sobno bilje-kompendij. Mostar: Agromediteranski fakultet Univerziteta "Džemal Bijedić" u Mostaru. 
B. Dorbić, Tea Zemunović, Emilija Friganović, Elma Temim, Ž. Španjol, Katica Arar / Stavovi i percepcije kninskih srednjoškolaca o uzgoju i primjeni sobnog... / Glasilo Future (2019) 2 (3) 29-45

Dorbić, B., Marić, A., Čuturić, T., Temim, E., Gugić, M., Šarolić, M., Gugić, J., Šuste, M., Zrno, Ž., Hadžiabulić, A. (2018). Istraživanje preferencija u odabiru sobnog bilja za interijere na primjeru Veleučilišta "Marko Marulić" u Kninu. Glasnik Zaštite Bilja, 41(4), 4-10.

Doxey, J.S.. Waliczek, T. M., Zajicek, J.M. (2009). The Impact of Interior Plants in University Classrooms on Student Course Performance and on Student Perceptions of the Course and Instructor. HortScience, 44(2).

Dravigne, A., Waliczek, T. M.., Lineberger, R. D., Zajicek, J. M. (2008). The effect of live plants and window views of green spaces on employee perceptions of job satisfaction. Hort Science, 43, 183187.

Fjeld, T., Veierstedb, B., Sandvike, L., Riisec, G., Levyd, F. (1998). The effect of indoor foliage plants on health and discomfort symptoms among office workers. Indoor Built Environ. 7, 204-209.

Geza, P. (2004). Kućne biljke. Zagreb: Nova knjiga Rast.

Hessayon, D. G. (2002). Sobno bilje. Zagreb: Mozaik knjiga.

Herwig, R. (1975). Sobno i vrtno cvijeće. Zagreb: Grafički zavod Hrvatske.

Ke-Tsung Han (2008). Influence of Limitedly Visible Leafy Indoor Plants on the Psychology, Behavior, and Health of Students at a Junior High School in Taiwan. Environment and Behaviour, 41(5), 658-692.

Larousse (2001). Kućni vrtovi i uređenje interijera. Zagreb: Veble commerce.

Martin, J. (1986). Kućno bilje. Zagreb: Naprijed.

Squire, D. (1996). Slikovna enciklopedija kućnih biljaka. Rijeka: Leo commerce.

Ströll, A. (1900). Pučko školstvo u Dalmaciji od godine 1814. do godine 1900. Zadar: Tiskara Petra Jankovića.

Taylor, A. F., KuoF, E., Sullivan, W. C. (2001). The surprising connection to green play settings. Environ. Behav, 335-477.

Ulrich, R., Simons, R., Losito, B., Fiorito, E., Miles, M., .Zelson, M. (1991). Stress recovery during exposure to natural and urban environments. J. Environ. Psychol.1120-1230.

Vigato, T. (2008). Izvannastavne aktivnosti u obrazovanju narodnih učitelja u Zadru. Časopis za suvremenu povijest 2, 373-395. 
B. Dorbić, Tea Zemunović, Emilija Friganović, Elma Temim, Ž. Španjol, Katica Arar / Stavovi i percepcije kninskih srednjoškolaca o uzgoju i primjeni sobnog... / Glasilo Future (2019) 2 (3) 29-45

Zemunović, T. (2018). Stavovi i percepcije kninskih srednjoškolaca o uzgoju i primjeni sobnog bilja. Završni rad. Veleučilište "Marko Marulić" u Kninu.

Primljeno: 05. prosinca 2019. godine

Prihvaćeno: 30. prosinca 2019. godine
Received: December 05, 2019

Accepted: December 30, 2019 